\title{
Palestinian Christians in the Mandate Department of Antiquities: History and Archaeology in a Colonial Space
}

\author{
Sarah Irving
}

When British forces took Palestine from the Ottomans in 1917, the territory's antiquities were high on their list of priorities. Fuelled by a long-standing British Protestant interest in-not to say obsession with-the Holy Land, measures to establish control over and soi-disant protection of ancient and historic sites were quickly rolled out. These were in some respects the logical conclusion of decades of European and American archaeological interventions in the region in which investigation of tells ${ }^{2}$ and other sites was often paired (especially in the British and American expeditions) with the desire to "prove" Biblical narratives and identify existing Palestinian sites with places named in scripture. But Mandate antiquities policy was also a multi-layered strand of cultural diplomacy, asserting British stewardship of the Holy Land

\footnotetext{
${ }^{1}$ As most comprehensively described and analysed by Eitan Bar-Yosef in The Holy Land in English Culture 1799-1917: Palestine and the Question of Orientalism (Oxford: Clarendon Press, 2005).

${ }^{2}$ In archaeological parlance, a tell (from the Arabic for hill) is an artificial mound, often as large as a natural hill, which is composed of centuries or millennia of deposits from sequential layers of occupation. It is best-known as a Middle Eastern phenomenon, resulting from the use of mud brick for a large proportion of buildings, as this breaks down to form layers, unlike stone or wood.
}

S. Irving $(\bowtie)$

Edge Hill University, Ormskirk, UK

e-mail: sarah.irving@edgehill.ac.uk

(C) The Author(s) 2021

K. Sanchez Summerer and S. Zananiri (eds.), European Cultural

Diplomacy and Arab Christians in Palestine, 1918-1948, https://doi.org/10.1007/978-3-030-55540-5_9 
to international audiences, and playing a role in how the authorities communicated with and sought to influence the inhabitants of Palestine.

Studies of how the Department of Antiquities interacted with the various populations of Mandate Palestine, imposed its powers and concepts of the past, and shaped the future of archaeology, archaeologists and antiquities institutions in Israel, Jordan and the Occupied Palestinian Territories are still fragmentary. ${ }^{3}$ This chapter explores one aspect of the Department's history, that of its Christian Arab staff, by tracing the lives and careers of two men who spent several decades working there. The notion of cultural diplomacy is useful here in several respects, while the discussion also reflects upon recognised problems in the cultural diplomacy literature, namely the absence of reception and reactions among target populations. ${ }^{4}$ Firstly, the Christian employees of the Department tended to be products of pre-WWI cultural diplomacy by those imperial powers which sponsored education in Palestine in order to expand their influence in the region. Secondly, as staff in a Mandate Administration department, they were part of the exercise of cultural diplomacy by the British, who sent messages both to the populations they ruled and to other colonising states through their handling of matters of culture, be they antiquities and history or other fields. And thirdly, we might see the actions of at least some of those Palestinians working for the Department as a form of subaltern cultural diplomacy, as they used the processes and findings of archaeology, translation, cultural explication and museum displays to make their own points about identity and history in this contested environment.

The information which can be reconstructed on the working environments, personal lives and publications of Stephan Hanna Stephan and Na'im Shehadi Makhouly highlight the diversity within the sometimes catch-all notion of Palestinian Christians in the Mandate period. It makes clear the need to consider a range of factors as complicating elements in their interactions with the Mandate authorities. These include proximity to the cultural and political "core" of Jerusalem, denominational background, sense of identity and political viewpoint. Following the careers of Stephan and Makhouly

\footnotetext{
${ }^{3}$ There are a number of histories of the development of 'modern' archaeology and of antiquities departments in Egypt (including those by D. M. Reid, mentioned below, but for the Mashriq the only overview of national archaeological institutions is Elena Corbett's Competitive Archaeology in Jordan: Narrating Identity from the Ottomans to the Hashemites (Austin: University of Texas Press, 2014). Zeynep Celik has also done valuable work on archaeological institutions during the Ottoman period, particularly in Turkey and Iraq (About Antiquities: Politics of Archaeology in the Ottoman Empire [Austin: University of Texas Press, 2016]), as have Edhem Eldem and Zainab Bahrani (Scramble for the Past: A Story of Archaeology in the Ottoman Empire, 1753-1914 [Istanbul: SALT/Garanti Kültür, 2011]). The rupture of 1948 and the ongoing tendency towards obsessive interest in the Biblical aspects of Palestinian antiquity, however, seem to have resulted only in studies which tackle specific aspects or themes, and which often frame Palestinian archaeology as that of the 'Holy Land.' See Footnote 6 for examples.

${ }^{4}$ Clarke, "Theorising the Role," 149.
} 
beyond 1948 also shows how the impacts of Mandate structures extended beyond the life of British rule, with Palestinians who had worked for the British remaining embedded in its colonial institutions and in the operation of cultural diplomacy as a means by which Britain retained a place on the world stage as its overt colonial power declined.

In taking a microhistorical approach, focusing on the lives and works of Stephan and Makhouly, this chapter adds granularity to the existing literature, which tends to concentrate on institutions and/or ideas, privileging narratives and experiences of the white, British men of the Mandate administration or of the institutions they ran and imposed on others. ${ }^{5}$ Studies of, for instance, the history of Biblical themes in Euro-American archaeology in Palestine are undoubtedly important in tracing how orientalist thought operated to reinforce colonial domination in Palestine. This paper instead seeks to contribute to knowledge and analysis of a different strand of Palestinian history, focusing on the dynamics of cultural diplomacies for the colonised population, in this case those working for the Department of Antiquities itself, and the complex tensions of identity and structural position that their professional positions entailed. It also intervenes in the ongoing debate over culture and identity under colonial regimes: had Palestinian Arabs who worked for the British Mandate Department of Antiquities, operating within the disciplinary terms of Western archaeology, been "ensnared" and become "lost to their people", as Frantz Fanon saw them? ${ }^{6}$ If so, in the Palestinian context, does this label Christian communities, which often had more educational, religious or professional contact with missionaries, foreign visitors and later the Mandate authorities, as more susceptible to colonisation? Or were they, consciously or not, using the resources of the colonial regime to research, record and protect their heritage at a time when its ownership and meaning was fiercely contested?

\footnotetext{
${ }^{5}$ See, for example, Thomas Davis, Shifting Sands: The Rise and Fall of Biblical Archaeology (Oxford: Oxford University Press, 2004); Shimon Gibson, "British Archaeological Institutions in Mandatory Palestine, 1917-1948," Palestine Exploration Quarterly 131, no. 2 (1999): 115143; Burke Long, Planting and Reaping Albright: Politics, Ideology, and Interpreting the Bible (University Park, PA: Penn State University Press, 2010); P. R. S Moorey, A Century of Biblical Archaeology (Cambridge: Lutterworth Press, 1991); John Moscrop, Measuring Jerusalem: The Palestine Exploration Fund and British Interests in the Holy Land (Leicester: Leicester University Press, 2000); Neil Silberman, Digging for God and Country: Exploration in the Holy Land, 17991917 (New York: Anchor Books, 1982); Amara Thornton, "Archaeologists-in-Training: Students of the British School of Archaeology in Jerusalem, 1920-1936," Journal of Open Archaeology Data 1 (2012). A valuable contribution which bucks this trend is Daniella Talmon-Heller's chapter on the Arab scribe who aided the Palestine Exploration Fund's Survey of Western Palestine, "Job (Ayyūb), Husayn and Saladin in Late Ottoman Palestine: Religious Life and Local History in the Memoirs of Nu'mān al-Qasātlīi, the Arab Scribe of the Survey of Western Palestine, and Beyond," in Exploring the Holy Land: 150 Years of the Palestine Exploration Fund, eds. David Gurevich and Anat Kidron (Sheffield: Equinox Publishing, 2019) which, along with my own research on Yusif Khazine and Yusif Kana'an, who worked for the PEF prior to WWI, helps bring to light the involvement of local figures in imperial archaeology in Palestine.

${ }^{6}$ Frantz Fanon, The Wretched of the Earth, trans. Richard Philcox (New York: Grove Press, 2004), 148
} 


\section{The Palestine Mandate Department of Antiquities}

Although the pre-WWI European and American organisations set up to excavate and explore the "Holy Land" and the discourses which gave rise to them have been widely studied, there is still no comprehensive study of the history and operations of the British Mandate administration's Department of Antiquities. The lives of some individuals who worked in the Department have been examined, but these are primarily British staff who occupied senior positions. ${ }^{7}$ The process of tracing the histories and works of most of the Arab Palestinian employees is, with the exception of Donald Whitcomb's articles on Dimitri Baramki, an ongoing process. This gap in the historical knowledge contributes to somewhat fragmented and one-dimensional understandings of the role and functions of the Department and its relationships with the indigenous inhabitants of Palestine. Articles ${ }^{8}$ which touch on the subject often rely on the archaeologist Albert Glock's unnuanced and sometimes inaccurate article ${ }^{9}$ and dictionary entry ${ }^{10}$ which, seeing the social and political dynamics of Mandate Palestine solely through the lens of Zionist colonialism, use raw numbers of the employees of the Department to draw conclusions about the biases which drove its decision-making. The result is a somewhat monolithic image which obscures variation within the staff of the Department and change over time in its policies, practices and staffing, and attributes little agency to Palestinians themselves.

A full description of the Department of Antiquities is outwith the scope of this chapter, but some idea of its workings is necessary to understand much of the discussion. Based, like most other divisions of the Mandate administration, in Jerusalem, the "Blue Book" official records show its growth from the early 1920s to the late 1940s. In 1926, it was headed by a director (always an archaeologically trained British official, starting with the well-known figure of John Garstang). Below him was a chief inspector and an inspector of antiquities, also both based in Jerusalem; assistant inspectors (at this time Jacob Ory in Jaffa and Na'im Makhouly in Acre) fulfilled this role in other regions of Palestine. The position of student inspector-a trainee role which was, over the period of the Department, filled by Dimitri Baramki (1909-1984), Salem al-Husseini (1905-1984) and Awni Dajani (?-1967)—was at the time empty,

\footnotetext{
${ }^{7}$ Examples include John Green's "Archaeology and Politics in the Holy Land: The Life and Career of P. L. O. Guy," Palestine Exploration Quarterly 141, no. 3 (2009): 167-187, the copious obituaries of figures such as John Garstang, R. W. Hamilton and C. N. Johns, and the books listed in $\mathrm{n} 4$.

${ }^{8}$ For example: Irene Maffi, "The Emergence of Cultural Heritage in Jordan: The Itinerary of a Colonial Invention," Journal of Social Archaeology 9, no. l (2009): 17.

${ }^{9}$ Albert Glock, "Cultural Bias in the Archaeology of Palestine," Journal of Palestine Studies 24, no. 2 (Winter, 1995): 48-59.

${ }^{10}$ Albert Glock, Lois Glock and Nancy Lapp, "Archaeology," in Encyclopedia of the Palestinians, ed. Philip Mattar (New York: Infobase Publishing, 2005), 74-75.
} 
with Baramki joining in 1927. Supporting these professional staff, who handled archaeological preservation and exploration across Palestine, were manual labourers, guards and messengers. Secretarial support was supplied from the civil service pool. Alongside the excavators were those whose roles focused on finds, archives and displaying the department's work to the public, initially in a small museum comprising just a few rooms. In 1926 these were a departmental and museum assistant (the numismatist C. Lambert) and a museum assistant whose position was also empty. ${ }^{11}$ Although unlisted in the Blue Book, Stephan Hanna Stephan had been seconded to the library by this time.

By 1944 the situation shows both continuity and change. There is still a director, R. W Hamilton, supported by a field archaeologist (Cedric Johns) and four full inspectors-Ory (now in Tulkarm), Makhouly, who had moved to Nazareth, Baramki and Husseini, both of whom had risen through the ranks after being recruited as students. The opening of the Palestine Archaeological Museum in the 1930s increased the Jerusalem-based staff considerably: John Iliffe was keeper of the museum, with Dimitri Baramki's brother Jalil and Immanuel Ben-Dor as assistant keepers. The Library was headed by Walter Abel Heurtley; Stephan Stephan was his assistant there but still does not appear in the Blue Book listings because he was still technically seconded from the general civil service. William Boyd Kennedy-Shaw was departmental assistant, providing support to the director, while the museum's growing collections demanded a specialist chemist (Haroutune Jamil Haleblian) and formatore ${ }^{12}$ (Mubarak Saad). ${ }^{13}$ Discussions found in the internal files of the department and its communications with departments such as the treasury show that the museum also employed more ungraded staff including guards, nightwatchmen and museum attendants, some of whom had power of arrest in case of theft or disruption. ${ }^{14}$ The Palestine Museum was a substantial and prestigious addition to the British administration's armoury when it came to cultural diplomacy, showing to international audiences the importance of Britain's self-imposed role as protector and explicator of the Holy Land's ancient remains. But it was also a contested space. The Museum's staff made decisions about what finds were displayed, how they would be labelled and what interpretations would be foregrounded, but internal correspondence shows that they were under considerable pressure from different groups to present particular narratives and, in particular, to provide all materials in the three official languages of the Mandate.

${ }^{11}$ Palestine Blue Book 1926, 45.

${ }^{12} \mathrm{~A}$ technical role involving making models and casts in wax, plaster and other materials.

${ }^{13}$ Palestine Blue Book 1944, 480.

${ }^{14}$ National Library of Israel folders 'Power of arrest for museum and library attendants: Antiquities Ordinance' (26/22) and 'Establishment list, Department of Antiquities, Palestine Archaeological Museum, 1929-35' (23/18). 


\section{Palestinians in the Department of Antiquities}

How should we view the positions of Palestinian Arabs who worked for the Department of Antiquities (and, indeed, other divisions of the British Mandate Administration), how were they seen by other Palestinians and how did they understand their own roles? To some of the rebels of the 1936-1939 Palestinian Uprising, anyone working for the British was a traitor who should withdraw their labour or face punishment. ${ }^{15}$ In Albert Glock's narrative of the Department, focusing on its colonial nature and the disproportionate numbers of recently immigrated Jews in its upper ranks, Palestinians were sidelined victims of a colonising system. ${ }^{16}$ Ilana Feldman's historical ethnography of Mandate employees in Gaza, however, shows that most saw themselves as possessed of agency, negotiating their way between jobs in which they perceived themselves as able to serve their own people, versus police and other security roles which they viewed as potentially collaborating with repression. ${ }^{17}$ Stephan's own letters reveal a blend of intellectual and cultural self-confidence ${ }^{18}$ with elements of colonisation, as when he writes to Finnish anthropologist Hilma Granqvist that: "We never had this idea [of studying women and peasant societies] and have to learn a lot from the West. We just have to prove that we Orientals are students who are quick and eager to learn". ${ }^{19}$

What these varying examples highlight is that blanket assumptions about colonialism or westernisation do not fit the lived experiences of Palestinian Arabs working for the Mandate administration. Glock stresses the large numbers of Arabs working in the lower ranks of the Department of Antiquities, as guards, messengers and labourers, while Jewish employees, from a much smaller fraction of the population, occupied better paid and more prestigious roles. He acknowledges that this is the result of highly educated Jews moving to Palestine (Leo Mayer, for example, already had a $\mathrm{PhD}$ from the Institute of Oriental Studies in Vienna when he joined the Department in the early 1920s), but places the blame for the lower number of educated Arabs on the staff squarely with the British. The practicalities of the situation, though, challenge this logic. The number of Palestinians with education and training

\footnotetext{
${ }^{15}$ Ilana Feldman, Governing Gaza: Bureaucracy, Authority and the Work of Rule, 1917-67 (Durham: Duke University Press, 2008), 82-84; W. F. Abboushi, "The Road to Rebellion: Arab Palestine in the 1930s," Journal of Palestine Studies 6, no. 3 (1977): 42; Hillel Cohen, Army of Shadows: Palestinian Collaboration with Zionism, 1917-1948 (Berkeley: University of California Press, 2008), 103-104.

${ }^{16}$ Glock, "Cultural Bias," and Glock, "Archaeology."

${ }^{17}$ Feldman, Governing Gaza, 82-84.

${ }^{18}$ Stephan Hanna Stephan to Hilma Granqvist, 15 April 1932. Palestine Exploration Fund, Granqvist file, unnumbered; 27 March 1934, Granqvist file doc 370; 17 March 1932, 367.

${ }^{19}$ Stephan Stephan to Hilma Granqvist, 15 April 1932. PEF Granqvist archive, unnumbered.
} 
in the field was significantly lower and the Department, operating with a fairly small budget, was required to quickly establish itself and then to inspect a large area with scant resources.

The Department does seem to have provided training for Arab candidates from early in its operation, as we shall see in the case of Na'im Makhouly. The Department's hiring of young Arab men who were trained and acquired degrees later on is also apparent in the cases of Dimitri Baramki and Salem Abdulsalam al-Husseini, both of whom went on to have successful archaeological careers; Husseini gained a degree from the American University of Beirut and Baramki (having started as a student inspector at the age of only 17) acquired a University of London degree by distance learning. ${ }^{20}$ Is it also worth noting that, in the economic setting of Mandate Palestine, government jobs were comparatively well-paid, desirable and prestigious in the eyes of much of the Palestinian population ${ }^{21}$; surviving archives show that even the gruelling position of resident site guard at Athlit Castle near Haifa was much sought-after and fought-over by both local men and those from across the region. ${ }^{22}$

The British presence could not, by any stretch of the imagination, be called anything but colonial, and the aims of political Zionism in Mandate Palestine must equally be termed settler-colonial. But in the context of this paper, attempting to consider how Christian Palestinians of the Mandate period viewed and experienced the Department of Antiquities and the discipline of archaeology, what other criteria should be applied? There are undoubtedly criticisms to be made of the British failure to apply the tutelary function of its Mandate trust equitably between Jews and Arabs (as well as of the entire Mandate concept itself), and access to government jobs was a long-standing subject of complaint and tensions between Jews and Arabs. ${ }^{23}$ But within the confines of a small department, some Palestinians did access training, career advancement and, presumably, intellectual satisfaction. It can

${ }^{20}$ Donald Whitcomb, "Dimitri Baramki: Discovering Qasr Hisham,” Jerusalem Quarterly 55 (2013): 79; Glock et al., "Archaeology," 74-75.

${ }^{21}$ Feldman, Governing Gaza, 70-76.

${ }^{22}$ Israel Antiquities Authority digital archive, correspondence folder on "Guard Abdallah el Masri," The file contains letters and reports on El Masri from the 1930s and 1940s, covering his working conditions, absences etc., his rejection of allegations which led to the termination of his employment, and the negotiations which the Department had to go through with the nearby village, the inhabitants of which objected to a stranger being given the job and stated repeatedly that it should be given to a man from among their number.

${ }^{23}$ Jacob Norris, Land of Progress: Palestine in the Age of Colonial Development, 1905-1948 (Oxford: Oxford University Press, 2013), 173; Weldon Matthews, Confronting an Empire, Constructing a Nation: Arab Nationalists and Popular Politics in Mandate Palestine (London: I.B. Tauris, 2006), 172; Zachary Lockman, Comrades and Enemies: Arab and Jewish Workers in Palestine, 1906-1948 (Berkeley: University of California Press, 1996), 101, 112, 180. 
be argued that in order to do so they had to conform to Western ideas of scholarship and of Eastern culture and history; ${ }^{24}$ on the other hand they also took some of those ideas and reshaped them to their own purposes. ${ }^{25}$

As well the general question of the uneasy relationship between the employees of the Department of Antiquities and British colonial rule is that of whether religion played a part in how Palestinian Arabs encountered the antiquities authorities and their ideas. Certainly Christians are more visible than Muslim Palestinians in the historical record of the Department: the most successful archaeologist among the Arab staff, Dimitri Baramki, was Christian, educated at the Anglican St George's School in Jerusalem, as was his brother Jalil, who worked for the Department for a while before switching to law. ${ }^{26} \mathrm{Na}$ 'im Makhouly was Orthodox, educated in a Russian school in Nazareth, ${ }^{27}$ and Stephan came from the Beit Jala Syriac community and was educated by the German Protestants of the Schneller School. ${ }^{28}$ Mubarak Saad, also Christian, was hired as a formatore around $1930,{ }^{29}$ continuing to work at the Palestine Archaeological Museum after its transfer to Jordanian management in 1948; his son Yusif/Joseph became the Museum's secretary. ${ }^{30}$ A specialist chemist with the Armenian name of Haroutune Jamil Haleblian appears in the records sometime in the 1930s and stayed until at least $1945^{31}$; this is probably the Haroutyun Jamil Haleblian (born in Aintab/Gaziantep) who graduated in pharmacy from the Syrian Protestant College in 1915 and in the intervening period worked at the government hospital in Hebron. He was listed in the university's records as Protestant. ${ }^{32}$

Among those Arab staff of the Department of Antiquities whose names appear in written sources, therefore, only Salem Abdulsalam al-Husseini, a

\footnotetext{
${ }^{24}$ Nadia Abu El-Haj, "Producing (Arti)Facts: Archaeology and Power During the British Mandate of Palestine," Israel Studies 7, no. 2 (2002): 33-36, 40-41.

${ }^{25}$ Sarah Irving, "Stephan Hanna Stephan and Evliya Çelebi's Book of Travels," in Cultural Entanglement in the Pre-Independence Arab World, eds. Anthony Gorman and Sarah Irving (London: I.B. Tauris, 2020), 217-237.

${ }^{26}$ Whitcomb, "Dimitri Baramki," 79.

${ }^{27}$ Ali Zgaier, “Rasa'il wa-taqrir katabha mufattish al-athar Na'im Makhouly min Kufr Yasif” (Letters and reports written by Antiquities Inspector Na'im Makhouly from Kufr Yasif), $A l$ Madar, 14 August 2016 (http://www.almadar.co.il/news-12,N-66149.html), accessed February 2019.

${ }^{28}$ Sarah Irving, "A Young Man of Promise: finding a Place for Stephan Hanna Stephan in the History of Mandate Palestine," Jerusalem Quarterly 73 (2018): 43.

${ }^{29}$ Palestine Blue Book 1930, 119.

${ }^{30} \mathrm{R}$. W. Hamilton, Letters from the Middle East by an Occasional Archaeologist (Durham: Pentland Press, 1992), 61, 102, 132.

${ }^{31}$ Palestine Blue Book 1939, 480; Blue Book 1945, 480.

${ }^{32}$ Hratch Yervant Kestenian, "A Portrait of Armenian Student Life at the Syrian Protestant College, 1885-1920" (MA thesis, American University of Beirut, 2015), 114.
} 
student and then full inspector in the 1930s and 1940s, and Awni Dajani, who joined as an inspector in the final years of the Mandate, were Muslim, both from eminent Jerusalem families. However, among the guards, doormen and labourers of the Palestine Archaeological Museum and the many excavations and historical sites for which the Department had ongoing responsibility, it is likely that the majority were Muslims, although the archives show that they did include both Christians and Jews. This difference is down to various factors, including the varying educational access between different religious communities, the apparent preference of some British administrators for Christian over Muslim employees and, sometimes, the political positions of different denominations vis-a-vis the British. ${ }^{33}$ Usually absent from this discussion, though, is the role of a kind of core-periphery dynamic: the Department of Antiquities, in common with almost all central offices of the Mandate administration, was based in Jerusalem, and this city was home to a much higher proportion of Jews and Christians than almost anywhere else in Palestine. At elite levels, this made less difference (hence the presence of Muslim Jerusalemites Husseini and Dajani), but when we encounter names among the Department's manual workers which are likely to be Christian it is mainly in Jerusalem. ${ }^{34}$

Overall, then, it seems likely that Christians had few formal advantages over Muslims when it came to accessing jobs at the Department of Antiquities. But being Christian did intersect with trends in education, location and language which disproportionately favoured this community among Palestinian Arabs and which were encouraged by a colonial environment. The small number of cases involved makes more generalisation impossible-we cannot, for example, identify specific schools or churches which sent more young men into archaeological training or to the Museum, as would be possible if analysing the intake of, for instance, the Government Arab College or American University of Beirut. There are simply too few examples on which to draw. What we seem to witness among Palestinian Arabs employed in white-collar roles by the Department of Antiquities is that Western-style educations, language skills and intellectual frameworks were privileged, and this created a space into which middle-class urban Christians and a smaller number of urban Muslim notables could enter, but which was closed to those with more traditional Islamic educations.

\footnotetext{
${ }^{33}$ Noah Haiduc-Dale, Arab Christians in British Mandate Palestine: Communalism and Nationalism 1917-48 (Edinburgh: Edinburgh University Press, 2013), 13, 23, 32 et passim; Laura Robson, Colonialism and Christianity in Mandate Palestine (Austin: University of Texas Press, 2011), 17, 22-25 et passim.

${ }^{34}$ Lists of Department staff which lead to this conclusion can be found in Department of Antiquities files in the Israel National Archives, including the draft estimates file for $1937 / 38$ $(4310 / 6)$ and especially the unusually comprehensive listings in the estimates files for 1946/47 $(147 / 43)$ and $1947 / 47(178 / 4)$.
} 


\section{Stephan Hanna Stephan and Na'im Shehadi Makhouly}

Stephan Hanna Stephan was born in 1894 in the town of Beit Jala, abutting Bethlehem, to a Syriac Orthodox family, and was educated at the German Lutheran-run Schneller School (the Syrian Orphanage), one of the most significant sites of German soft power in Palestine. ${ }^{35}$ The Syriac Orthodox formed a small community which was uncomfortably combined with the larger Armenian church under Ottoman rule and was thus doubly marginal, relative to the richer and more numerous Greek Orthodox and other denominations. ${ }^{36} \mathrm{He}$ joined the British Mandate administration as a general civil servant, starting at the Treasury, but some of his earliest published writings (from 1921/22) show his existing interest in the culture and history of Palestine from a perspective which means that he is often included in the notional "Canaan circle" of nativist ethnographers who "challenged a colonial British version of Palestinian history that saw Arabs in Palestine as transient and ephemeral". ${ }^{37}$

In works such as his translations of the Palestine sections of Evliya Çelebi's Seyahatname, ${ }^{38}$ his "Modern Palestinian Parallels to the Song of Songs", ${ }^{39}$ and several guidebooks for English-speaking visitors during World War II, Stephan asserted a strong and distinctive Palestinian culture which can be seen as a kind of subaltern cultural diplomacy, using historical, cultural and religious themes both to assert Palestinian legitimacy against Zionism claims, and to suggest commonalities between Palestinian Christians and their European and American co-religionists. ${ }^{40}$ In Stephan's portrayal, Palestinian culture had several defining features, including roots in a rich and diverse blend of cultures, and the presence within its contemporary manifestation of instances of modernity which refuted Zionist claims to have brought civilisation to the Arab population of Palestine. His mid-1930s publication of Arabic manuals and phrasebooks for English- and German-speaking learners also fits into the general idea of the Arabic language as a unifying factor among Muslim and Christian Arabs. ${ }^{41} \mathrm{He}$ intervened in debates in Arabic-speaking

\footnotetext{
${ }^{35}$ Irving, "Young Man of Promise," 43.

${ }^{36}$ Heleen Murre-van den Berg, "A Center of Transnational Syriac Orthodoxy: St. Mark's Convent in Jerusalem," Journal of Levantine Studies 3, no. 1 (2013): 61, 71.

${ }^{37}$ Khaled Furani and Dan Rabinowitz, "The Ethnographic Arriving of Palestine," Annual Review of Anthropology 40 (2011): 479; Salim Tamari, Mountain Against the Sea (Berkeley: University of California Press, 2009), 93-111.

${ }^{38}$ Irving, "A Young Man of Promise," 47-55.

${ }^{39}$ Journal of the Palestine Oriental Society 2 (1922): 199-278.

${ }^{40}$ Irving, "Young Man of Promise," 47-55.

${ }^{41}$ K. M. J. Sanchez Summerer, "Preserving the Catholics of the Holy Land or Integrating Them into the Palestine Nation (1920-1950)?" in Modernity, Minority, and the Public Sphere: Jews and Christians in the Middle East, eds. S. R. Goldstein-Sabbah and H. L. Murre-van den Berg (Leiden: Brill, 2016), 140-142; Haiduc-Dale, Arab Christians, 30-31.
} 
intellectual and educational circles, delivering talks on the Palestine Broadcasting Service's Arabic radio on Palestinian history and folklore, ${ }^{42}$ commenting on the rights of women in Arab societies for the Nahda journal Sarkis, ${ }^{43}$ and contributing articles and letters on Palestinian history and culture to the pages of Arabic newspapers published in Cairo and Jerusalem. ${ }^{44}$

At the Department of Antiquities and later the Palestine Archaeological Museum Stephan was largely based in the library, first on secondment from the general civil service pool, and in later years as a full member of the department. ${ }^{45}$ Without a formal university education he seems never to have been considered eligible for the librarian's position, but was an assistant. Despite this, he appears to have built up a considerable reputation in the region, authoring a bibliographic work for a series at the American University of Beirut and becoming known in Jerusalem's scholarly circles for his linguistic prowess. ${ }^{46}$ The Department of Antiquities recognised the value of Stephan's translations, mainly of Ottoman Turkish texts, and paid him extra for carrying them out. ${ }^{47}$ By the end of the Mandate period and in the immediate aftermath of the Nakba (when Stephan, his wife and their two sons became refugees in Lebanon), Stephan was travelling repeatedly to Cyprus to work on Arabic inscriptions there, and regularly took his children with him. ${ }^{48}$

Stephan never expressed overt political or religious opinions, unlike his counterpart at the Palestine Oriental Society, Tawfiq Canaan, who caused something of an uproar with his outspoken pamphlets at the beginning of the Palestinian Uprising in $1936 .{ }^{49}$ As a public employee, open political statements were forbidden. ${ }^{50}$ However, some of his writings suggest a sense of both Palestinian and Christian identity, to the extent of implicitly expressing a vision of the Palestinian future. In his translation and annotations to Evliya Çelebi's Seyahatname, there is a strong sense of the existence of a distinctly

\footnotetext{
42 Ibid., 51-52.

${ }^{43}$ Istefan Hana Istefan (Stephan Hanna Stephan), “al-Mar'a,” Majallat Sarkis 11, no. 1 (January 1922): 64-65.

${ }^{44}$ These included letters on the site of the grave of Christ in al-Siyasa al-Usbu'iyya ("mawqi' al-qabr al maqdis: rad "ala maqal," (The site of the Holy Sepulchre: response to article), 5 November 1927; I am indebted to Eli Osheroff for bringing these letters to my attention. The articles in Jerusalem papers were mainly on folk culture and local historical sites and appeared in al-Muntada, al-Dhakira and al-Minbar between 1943 and 1947.

45 “Appointments, Etc," Palestine Gazette 1521 (12 September 1946), 843.

${ }^{46}$ St. H. Stephan, A Post-War Bibliography of the Near-Eastern Mandates, 1919-1930 (Beirut: American University, 1936); Hilma Granqvist daybook 17 February 1931, Hilma Granqvists Arkiv http://granqvist.sls.fi, accessed March 2019.

${ }^{47}$ Irving, "Young Man of Promise," 47.

${ }^{48}$ Email from Cristina Stephan, 30 November 2016.

${ }^{49}$ Tawfiq Canaan, The Palestine Arab Cause (Jerusalem: The Modern Press, 1936); Conflict in the Land of Peace (Jerusalem: Syrian Orphanage Press, 1936).

${ }^{50}$ Feldman, Governing Gaza, 84 .
} 
Palestinian selfhood: this encompasses Muslim, Jewish and Christian faiths and urban and rural ways of life, and is seen as vibrant, deeply rooted in myth and scripture, prosperous and cultured..$^{51}$

His three tourist guidebooks, co-authored with photographer Boulus 'Afif, published during WWII and explicitly aimed at British and Commonwealth soldiers on leave in Palestine, present a similar image of a mixed and inclusive society (describing, for example, new Jewish towns as well as the older sites one might expect), but with a particularly Christian edge..$^{52}$ Only when dealing with Christian sites do they shift tone from businesslike guidance to deep reverence. ${ }^{53}$ It may be that, in stressing their Christian identities and the New Testament connections of Palestine, Stephan and Boulus sought to appeal to British Christian servicemen as part of the ongoing competition with Zionist writers to lay claim to Palestinian land and history. The depth of Stephan's personal religious convictions is impossible to know, but the guidebook suggests that he possessed enough of a Christian identity to feel comfortable operationalising it in order to propose a common ground between himself and his readers. The appearance of an overt strand of Christian identification in Stephan's writings in the 1940s, absent in earlier works, also accords with Noah Haiduc-Dale's observation that Christians in the early years of the Mandate had seen and shown themselves not as a minority, because they were part of the Arab majority, but that in the later period Christian minorityhood was asserted as a way of critiquing British policy. ${ }^{54}$ This also chimes with the fact that Stephan's writings for Arabic-language papers in the 1940s included entries in specifically Christian publications such as al-Minbar, whereas his earlier articles and letters had appeared in journals which emphasised a common Arab culture.

Na'im Makhouly's work at the Department of Antiquities was of a very different nature. Unlike Stephan's role in the library, dealing with books and manuscripts and translating documents, Makhouly's entailed travel from his headquarters in Acre and later Nazareth across the whole northern region of Palestine, to cities including Nablus, Jenin, Tabariyyeh, Akka and Haifa, and to towns and villages along the border with Lebanon and the Mediterranean coast. With a more limited range of publications, and fewer encounters with international scholars and other readers and audiences, his opportunitiesand, the evidence seems to suggest, his desire-to exercise a kind of antiquities-based cultural diplomacy were much more limited than Stephan's. Makhouly's example thus highlights the variation in Christian Palestinian

\footnotetext{
${ }^{51}$ Irving, "Book of Travels," n.p.

${ }^{52}$ Sarah Irving, "This Is Palestine': History and Modernity in Guidebooks to Mandate Palestine," Contemporary Levant (2019).

${ }^{53}$ Stephan Hanna Stephan and Boulus 'Afif, This Is Palestine: A Concise Guide to the Important Sites in Palestine, Transjordan and Syria (Jerusalem: Bayt-ul-Makdes Press, 1942), 14, 114.

${ }^{54}$ Haiduc-Dale, Arab Christians, 3, 61-62, 71-77, 87, 107-108.
} 
responses to, and use of, cultural diplomacy as a feature of their relations with the Mandate authorities.

Born in the town of Kufr Yasif, north of Akka, in 1898, Makhouly came from an Orthodox Christian family and, after primary education in Kufr Yasif (later dubbed by veteran Palestinian journalist Atallah Mansour "the most academic Arab town in Israel" ${ }^{55}$ ), went to the school in the Russian compound in Nazareth. ${ }^{56} \mathrm{He}$ then seems to have acquired training at the newly formed British School of Archaeology in Jerusalem, which in the early years of the Mandate was run in tandem with the Department of Antiquities by John Garstang. Makhouly does not appear in the formal lists of students of the School, ${ }^{57}$ but neither do other Arab students and later employees of the Department who are believed to have studied there. The logical conclusion seems to be that the "official" lists are of students of archaeology from British universities who came for fieldwork, but that the School also served as an instruction centre for the Department of Antiquities, and that Makhouly was the first of these unregistered trainees. ${ }^{58}$

Makhouly was employed in April 1922 as an Assistant Inspector of Antiquities for the northern region of Palestine, based initially in Acre and from 1939 in Nazareth. ${ }^{59}$ His job, as revealed by the Department of Antiquities files, was varied and involved much travel. Archaeological tasks included inspecting buildings and sites to see if they warranted protection and further investigation by the department, often under pressure if remains had been uncovered during construction or farming and the owners of the land needed to get on with their work. Frequently these inspections were brief affairs, resulting in a case folder containing one or two pro formas and a photograph or sketch plan of the site. Sometimes, however, they were major and protracted projects, as at Tell al-Hawwam near Haifa, which became a fullscale excavation and also embroiled Makhouly in a legal case against people accused of illegally digging for antiquities and disturbing the archaeological site. The accused, in their turn, pointed to the Shell Oil Company, whose refinery site (now Oil Refineries Ltd) occupied the adjacent plot. ${ }^{60}$ Conflict over archaeological finds and sites could at times turn nasty: guards and attendants at all protected sites-not just at the Archaeological Museum in

\footnotetext{
${ }^{55}$ Atallah Mansour, Narrow Gate Churches: the Christian Presence in the Holy Land Under Muslim and Jewish Rule (Pasadena: Hope Publishing House, 2004), 256.

${ }^{56}$ Zgaier, "Rasa'il wa-taqrir."

${ }^{57}$ Thornton, "Archaeologists-in-Training."

${ }^{58} \mathrm{I}$ am indebted to Dr Amara Thornton for our discussions of Makhouly's training and the likely explanations for the inconsistencies and gaps which appear in records on the British School of Archaeology in Jerusalem.

${ }^{59}$ Palestine Blue Book 1928, 111; Palestine Blue Book 1939, 480.

${ }^{60}$ Israel National Archives folder 25/20, "Destruction of an Illicit Digging for Antiquities at Tel Abu Hawam Near Haifa," 1929-1933.
} 
Jerusalem - had powers of arrest, and Makhouly himself had received threats in the course of his work. ${ }^{61}$

The conventional viewpoint on such cases is that the staff of the Department of Antiquities were preserving archaeological heritage, conceptualised as a kind of universal property. Nadia Abu El-Haj, however, stresses the extent to which ideas of archaeological protection, instituted in the Ottoman period and continued by the British, represented new claims to ownership which dislocated people from the parts of their surroundings which were labelled antique. ${ }^{62}$ The latter, in turn, focused on the Judaeo-Christian past and saw Islamic heritage, particularly that from the more recent Ottoman period, as less worthy of protection. Makhouly's own duties certainly involved interfering in the affairs of people who seem to have been accustomed to exploiting tells and ruins for earth, fertiliser and building stone, and who, with the imposition first of Ottoman antiquities laws and later the British regimen, were encountering a new set of rules governing interactions with their surroundings. ${ }^{63}$

Where finds proved of sufficient interest, Makhouly or one of his colleagues might also write them up for the Quarterly of the Department of Antiquities of Palestine, the administration's academic journal. ${ }^{64}$ Compared to his colleagues, though, Makhouly does not give the impression of being a keen writer, with markedly fewer publications than those of similar rank in the department, whether of Arab, Jewish or European origins. Those articles he did publish tend to be short and, like that on Jish, include long finds lists rather than descriptive or analytic text. One senses an archaeologist whose strength lay in the field and in the logistics and personal relations necessary to conserve the remains on his turf, rather than an academic who wanted to write long articles. One tendency of both Makhouly and Stephan's articles for QDAP is, however, striking. Among American and British excavators, including Makhouly and Stephan's contemporaries (such as DAP chief inspector in the 1920s P. L. O. Guy and the famous US archaeologist William Foxwell Albright, who headed the American School of Archaeology in Jerusalem during periods $1922-1929$ and $1933-1936^{65}$ ) there is an almost fanatical

\footnotetext{
${ }^{61}$ Letter from Director of Antiquities E. T. Richmond to Director of the Public Works Department, 9 July 1930, ATQ/235 (Israeli Antiquities Authority digital archive file "Khirbet al Hawam").

${ }^{62}$ Abu El-Haj, "Producing (Arti)Facts," 35-36, 40-42.

${ }^{63}$ Albert Glock, "Jenin," in Anchor Bible Dictionary (New York: Doubleday, 1992), 678-680.

${ }^{64}$ Makhouly's articles include a short piece on a number of stone seats found during construction of a hotel at Al-Hamma ("El Hamme: Discovery of Stone Seats," QDAP 6, no. 1 [1936], 59-62), a site report on excavations of a sixth-century synagogue at "Isfiya ("A sixth-century synagogue at "Isfiya. I excavation report by N. Makhouly; II The Mosaic Floor, the Inscription, Conclusion, by M. Avi-Yonah," QDAP 3 [1934], 118-144) and a report on a series of tombs and the finds from them at Jish ("Rock-Cut Tombs at El Jish," QDAP 8 [1938], 45-50).

${ }^{65}$ Both Guy and Albright's interpretations of archaeological sites attracted criticism, at the time or subsequently, for the extent to which they allowed their desires to discover sites of Biblical importance to lead them to questionable conclusions (Green, "Archaeology and Politics,"
} 
obsession with identifying the Biblical antecedents of archaeological sites. But neither of these Christian Palestinians, or their other Palestinian colleagues, adopted such a narrative. Na'im Makhouly's writings are scholastically dry and scientific in tone, eschewing any kind of opinion or personal comment, while Stephan's approach to the Palestinian past is very much in line with the "Canaan circle" notion of a diverse, blended history creating a richly patterned present.

Makhouly's best-known and most widely cited publication, his Guide to $A k k a$, is no exception. ${ }^{66}$ This was one of a series of guidebooks to Palestinian cities published by the Department of Antiquities which also included Bethlehem (by R. W. Hamilton), Megiddo (Shipton), Citadel of Jerusalem (C. N. Johns), Beisan (Ben-Dor) and Sebastieh (Hamilton). ${ }^{67}$ The Guide represents a useful point of comparison between Stephan and Makhouly's works. Stephan's writings display an underlying, or sometimes overt, sense of Palestinian identity and nationhood, and he published in Arabic, German and English in a range of journal and books which carried his ideas to diverse audiences. Makhouly, by contrast, seems only to have written for publication by his employers. The Guide to Acre, while undoubtedly a "local" 68 voice in some respects, often adopts a Eurocentric perspective. Of the 65-page historical introduction to the city, 20 pages deal with the Crusader period, while the "Mamluke and Early Turkish" section which follows is only two pages long, despite stretching from the late thirteenth-century to the eighteenth-century rebuilding of Akka under Daher al- Omar. ${ }^{69}$ The conquest of Acre by the Mamluks is termed its "fall", suggesting a Crusader rather than Egyptian viewpoint, and there are substantial quotations from medieval Christian writers of European origin, while excerpts from Arabic, Turkish and generally Muslim documents are confined to some paragraphs from the famous Andalusi traveller Ibn Jubayr. ${ }^{70}$

It may be that the very conventional language and narrative of the Guide derives from its status as a quasi-official publication, whereas Stephan's books were independently printed and his articles appeared in journals with a much smaller, and more academic, focus. The role of Makhouly's superior in the

171, 173; William G. Dever, "What Remains of the House That Albright Built?" The Biblical Archaeologist 56, no. 1 (1993): 25-35.

${ }^{66}$ Jerusalem: Government of Palestine Department of Antiquities/Azriel Press, 1941.

${ }^{67}$ Jean Perrot, "La Musée archéologique de Palestine, à Jérusalem," Syrie 25, nos. 3-4 (1946): 268-300.

${ }^{68}$ Amara Thornton, "Tents, Tours, and Treks: Archaeologists, Antiquities Services, and Tourism in Mandate Palestine and Transjordan," Public Archaeology 11, no. 4 (2012): 210.

${ }^{69}$ Makhouly, Guide to Acre, 21-41, 42-43.

${ }^{70}$ Ibid., 23-25. 
Department, field archaeologist C. N. Johns, may also play a part: the first edition of the Guide carries a preface by the Department's director, R. W. Hamilton, calling it "chiefly the work of Mr. Na'im Makhouly", but "assisted in its preparation" by Johns, who is said to have contributed "parts of the historical section" and "revised the whole work".7l One envisages Makhouly doing the leg-work, hunting around the Old City of Akka for sites and noting their locations and descriptions, while a second contributor adds historical narrative and fine-tunes the manuscript. By contrast, the closest analogue among Stephan's works - the Evliya translations, several of which were published with annotations by Department Librarian Leo A. Mayer-still maintains an aura of independence lacking in Makhouly's Guide.

Alongside carrying out actual archaeology, Makhouly had to play bureaucrat, logistics manager, construction overseer and writer. His job entailed liaising between different government departments, some of them with conflicting interests: at Acre (Akka), for instance, the city and sea walls were protected archaeological sites but also-especially the latter- vital parts of the town's infrastructure. ${ }^{72}$ Repairs to Akka's architectural heritage, combined with the Mandate administration's financial pressures, thus entailed convoluted arrangements and sometimes tetchy exchanges of notes on subjects such as which department had prior claim on supplies of building stone. ${ }^{73}$ When temporary local staff, such as surveyors, labourers and guards, had to be hired for ad hoc excavations, it was Na'im Makhouly who had to source them and negotiate rates of pay with the Jerusalem office; he might also be called upon to take photographs for visiting archaeologists, bring along a spade and measuring equipment if a senior colleague was visiting to inspect a site, or make recommendations to other government offices on whether land could be leased to farmers or used by a school as a playground or by the notorious Akka prison as a "criminal lunatics' exercise yard". ${ }^{74}$ Here there was little or no scope for articulating a particular identity; sites were examined whenever the Department was alerted to their discovery, and Makhouly's role in interpreting and extrapolating from larger excavations was limited.

${ }^{71}$ Ibid., iii.

${ }^{72}$ Letter from Director of Antiquities R. W. Hamilton to C. N. Johns, 31 August 1944; Letter from R. W. Hamilton to A/Director of Public Works, Jerusalem, 13 April 1944, ATQ/6/23 (Israel Antiquities Authority digital archive, 'Acre' folder); Jacob Sharvit and Dror Planer, "Akko, the Southern Seawall: Preliminary Report," Hadashot Arkbeologiyot 126 (2014).

${ }^{73}$ Letters between District Engineer, Haifa District and Director of Antiquities, Jerusalem, 11 July 1943 (ref 16/11); 30 May 1943 (ref 16/11); 18 May 1943 (ref ATQ/6/23) (Israel Antiquities Authority digital archive, 'Acre' folder).

${ }^{74}$ Letter from the Acting Director of Public Works to the Chief Secretary (copied to Director of Antiquities), "Exercise Yard for Criminal Lunatics Acre," 2nd October 1943 (ref. 2/6/1) (Israel Antiquities Authority digital archive, 'Acre' folder). 


\section{Stephan And Makhouly After 1948}

Makhouly and Stephan's trajectories after 1948 are also illuminating in respect both of the relationship between the Mandate administration and its Palestinian employees, and of the place of British cultural diplomacy in the Arab world. Both men became refugees in Lebanon, along with their families. Stephan, though, continued to carry out work for the British-run department of antiquities in Cyprus, similar to his Jerusalem specialisation in analysing texts and inscriptions. This is suggested by an article published after his death on an early Arabic inscription on a Cypriot tombstone; the article is authored by A. H. S. Megaw (1910-2006), head of antiquities on Cyprus, but Megaw states that it is based on notes made by Stephan before his demise. ${ }^{75}$ There is a logic to Stephan being asked to carry out work for the department in Cyprus, as he was an experienced and proven expert on such analyses and situated close by. Megaw had also been seconded to the Palestine Archaeological Museum to carry out surveys for the restoration of the Dome of the Rock in 1946, so the two men's acquaintance may have been founded several years earlier. ${ }^{76}$ One can only speculate on the possible course that Stephan's work in Cyprus might have taken had he lived longer, but his granddaughter's memory of her father's passport containing numerous Cypriot stamps from this period suggests that the family was hoping that the employment would be extended. ${ }^{77}$

By contrast, Na'im Makhouly and his family appear to have experienced financial hardship and trouble finding work in the immediate aftermath of 1948. Letters from Makhouly to his Jewish former colleagues, by then establishing the Israeli Antiquities Authority in the newly founded state, openly beg them to support his application to be allowed back into the country from Lebanon, and to help him find archaeological work. ${ }^{78}$ The responses from Emanuel Ben-Dor are chilly in the extreme and hold out no hope; those from other colleagues were a little warmer but promised nothing, and the family were-like most other Palestinian refugees-denied their pleas to return. Makhouly seems to have been out of work for a period of at least two years.

Then, in 1951, his former colleague C. N. Johns, with whom he had worked on the Guide to Acre, obtained a post for him in Libya, where Johns had been sent as the first Controller of Antiquities in Cyrenaica and Tripolitania. ${ }^{79}$ The new kingdom had narrowly avoided the imposition of a

\footnotetext{
${ }^{75}$ A. H. S. Megaw, "A Muslim Tombstone from Paphos," Journal of the Royal Asiatic Society of Great Britain and Ireland 3/4 (1950): 108-109.

${ }^{76}$ Israel National Archives folder 4311/22, "Proposal for Secondment of Mr A. H. S. Megaw, Director of Antiquities, Cyprus," 1945-1947.

${ }^{77}$ Email from Cristina Stephan, 30 November 2016.

${ }^{78}$ Raz Kletter, Just Past?: The Making of Israeli Archaeology (Sheffield: Equinox Publishing, 2006), 46-51.

${ }^{79}$ G. R. H. Wright, “Obituary: C.N. Johns,” Libyan Studies 24 (1993): iv.
} 
United Nations trusteeship similar to a League of Nations Mandate ${ }^{80}$ and was now formally independent, but with a strong British and US military and civilian presence propping up the government of King Idriss until the late 1960s. ${ }^{81}$ Along with some Italian archaeologists from the preceding colonial regime, antiquities thus again formed part of Britain's diplomatic activities, and Palestinian Arab archaeologists were entangled in this extension of British cultural diplomacy — or imperialism— to another Arab state. Makhouly wasn't the only Palestinian archaeologist to join the British-run antiquities department in Libya; his former colleague, Salem al-Husseini, worked there in roles which ranged from excavation director to archivist until his retirement in 1966, ${ }^{82}$ after spending several years working in a "footling" job as a liaison officer for UNWRA. ${ }^{83}$ Dimitri Baramki also dug in Libya and apparently renewed his acquaintance with Husseini, but this was in his capacity as a university professor, not an employee of the Libyan state. ${ }^{84}$

In Libya, Makhouly worked as a site supervisor and inspector, including on the University of Chicago excavations at Ptolemais ${ }^{85}$ but was deeply unhappy so far from his home and family, if his letters to Ben-Dor are any indication. ${ }^{86}$ This is not surprising of a man in his fifties who had lived and worked in the same region for his entire life, now completely displaced. His personal unhappiness was coupled with dissatisfaction at the conditions in Libya; he complained of being stationed in a "very poor and small village", where "I have nobody to talk to, so I spend my time in work, study, and food preparation". 87 The British authorities may have seen Makhouly as an "Arab", with more experience of working in English but otherwise of the same ilk as Libyans who had worked for the Italian colonial authorities before the war. Arab nationalist political narratives, meanwhile, would portray Makhouly and the workers he was overseeing as ethnic brothers. But Makhouly's letters suggest that he found himself in an archaeologically interesting but culturally barren environment, and that he felt isolated in north

\footnotetext{
${ }^{80}$ Benjamin Rivlin, "The Italian Colonies and the General Assembly," International Organization 3, no. 3 (August 1949): 461-463.

${ }^{81}$ Stephen Blackwell, "Saving the king: Anglo-American strategy and British counter-subversion operations in Libya, 1953-59," Middle Eastern Studies 39:1 (2003): 2-4; Richard John Worrall, "The Strategic Limitations of a Middle East Client State by the Mid-1950s: Britain, Libya and the Suez Crisis," Journal of Strategic Studies 30, no. 2 (2007): 312-316.

${ }^{82}$ Said Husseini, "Black and White Photograph of Salem Abdulsalam al-Husein," Palestine Museum digital archives, http://palarchive.org/index.php/Detail/objects/9187, accessed March 2019.

${ }^{83}$ Hamilton, Occasional Archaeologist, 131-132. Husseini stayed in touch with Hamilton, the last head of the Palestine Department, visiting him in Britain in 1977 (43).

${ }^{84}$ Whitcomb, "Dimitri Baramki," 79.

${ }^{85}$ Carl Kraeling, Ptolemais: City of the Libyan Pentapolis (Chicago: University of Chicago Press, 1962), v.

${ }^{86}$ Kletter, Just Past, 46-51.

${ }^{87}$ Ibid., 48 .
} 
Africa. Salem al-Husseini's opinions of his two decades in Cyrenaica are not a matter of record, but we can speculate that a Muslim may have found some common ground not available to Makhouly, whose Orthodox Christianity, so widespread in the Levant, was absent from Libya. One might also wonder how those Libyans employed by the Department of Antiquities felt about the Palestinians brought in by the British. Some went on to become noted archaeologists in their own right (such as Abdulhamid Abdussaid, who worked with Husseini ${ }^{88}$ and who, with a father who worked for the Italian colonial authorities at Cyrene, had grown up among archaeological remains $\left.{ }^{89}\right)$. Did they see the Levantines as fellow Arabs, or as adjuncts to the colonial system? And did that vary between men like Na'im Makhouly and Salem al-Husseini, shifting the focus of cultural diplomacy from a Christian to an Islamic milieu?

Stephan and Makhouly's post-Nakba careers, and the similarities and divergences between them, to some extent de-exceptionalise the Palestinian experience, highlighting the extent to which the Department of Antiquities in Palestine was part of a network of British colonial institutions which extended around the Mediterranean and beyond to other parts of the Empire. The movement of British, senior-level archaeologists within this is better acknowledged and understood, but the existence of a stratum of educated, professional men from colonised peoples for whom this network represented an opportunity for more or less willing mobility has been largely ignored, although its antecedents precede World War One. In the less institutionalised setting of the Late Ottoman Levant and Egypt, site supervisors (of whom the known examples are disproportionally Christian, although this may be an accident of the archives) moved between Lebanon, Palestine and Egypt on excavations funded by universities and exploration societies in Europe and America. ${ }^{90}$ In the interwar period linguistic, state and therefore professional borders hardened, but while Stephan and Makhouly's displacement was part of the creation of a Palestinian diaspora, their employment circumstances was part of a professional scattering which mapped onto colonial institutions

\footnotetext{
${ }^{88}$ John Griffiths Pedley, “The Archaic Favissa at Cyrene," American Journal of Archaeology 75 , no. 1 (1971): 39.

${ }^{89}$ Paul Bennett and Ahmed Buzaian, "Abdulhamid Abdussaid," Libyan Studies 48 (2017): $7-8$.

${ }^{90}$ Examples include the two Lebanese Christian overseers, Yusif Khazine and Yusif Kana'an, who worked for Frederick Jones Bliss and later Palestine Exploration Fund archaeologists between 1890 and 1913; Yusif Kana'an also worked for a German team digging at Baalbek around 1900 (Sarah Irving, "A Tale of Two Yusifs: Recovering Arab Agency in Palestine Exploration Fund Excavations 1890-1924," Palestine Exploration Quarterly 149 (2017): 223236); Donald Malcolm Reid's Whose Pharaobs?: Archaeology, Museums, and Egyptian National Identity from Napoleon to World War I (Berkeley: University of California Press, 2003) and Contesting Antiquity in Egypt: Archaeologies, Museums, and the Struggle for Identities from World War I to Nasser (Cairo: American University of Cairo Press, 2015) both chart the slow rise of professional Egyptian archaeologists despite the opposition of many colonial officials.
} 
and their appropriation of cultural assets, as it also did for other Palestine Department of Antiquities staff such as Dimitri Baramki and Awni Dajani. ${ }^{91}$ Clearly this was not solely a path trodden by Christians, but they were certainly over-represented proportional to their numbers in the Palestinian population.

\section{CONClusion}

The Department of Antiquities of the British Mandate administration in Palestine was many things. It was, as Abu El-Haj stresses, a colonial entity which, through laws, the operations of a colonising regime, academic disciplinary rules, and orientalist and class assumptions detached middle-class participants in its operations from parts of their intellectual heritage and ordinary Palestinians from their immediate environments. Ruins, buildings and remains were reclassified according to separations of religious and secular, antique and modern which did not accord with local lived experience. They were then brought under legal regimes which removed access and control from the bulk of the population. But the Department was also a working space in which on the one hand, Palestinian Arabs were under-represented according to their share of the population and their knowledge probably under-valued but where, on the other, some did find training, employment and even an apparent sense of meaning. Stephan, in particular, seems even to have found ways in which he could subvert the ideas and intellectual production of his working environment to create narratives which reinforced the idea of a diverse culture and people which defied the monolithic nationalisms of both Zionism and some Arab nationalisms.

Among those Palestinians who worked for the department in professional-level roles, the majority were Christian, entangling this community more tightly in the Mandate administration's cultural enterprises. As employees with general portfolios, few would have had scope to integrate their identities into their excavation and inspection work, if indeed they wanted to; more overt political statements were also forbidden by the terms of public employment. Baramki, indeed, spent many years, and established his wider renown

\footnotetext{
${ }^{91}$ Dimitri Baramki, who dug the famous 'Hisham's Palace' (Khirbet al-Mafjar) site in Jericho, spent a brief period after 1948 working for the Jordanian antiquities authority before leaving for Beirut, where he became Professor of Archaeology at the American University (Whitcomb, "Dimitri Baramki," 79). Much of his later work, and his fame outside the Levant, rest on his studies of the Phoenicians, which included a popular volume which appeared in both English and German; the subject matter could be interpreted as following a Christian Lebanese (specifically Maronite) concern with differentiating themselves from the Muslim Arab population of the region. Awni Dajani worked for the Jordanian Department of Antiquities after 1948, as director (1959-1968) he oversaw the first articles in Arabic in the department's journal (Maffi, "Emergence of cultural heritage in Jordan," 15); he is also known as the first Jordanian to earn a $\mathrm{PhD}$ in archaeology, having studied with Kathleen Kenyon in London (Miriam Davis, Dame Kathleen Kenyon: Digging Up the Holy Land [Abingdon: Routledge, 2016], 134, 163).
} 
on, his excavations at the Umayyad site of Khirbet al-Mafjar (Hisham's Palace) in Jericho, while Makhouly, Husseini, Dajani and Saad all worked on sites and finds allocated to them by chance. Only Stephan, with some apparent leeway in his discretionary translation work, used his annotations and choices as the translator of Evliya Çelebi's Seyahatname to make a statement about the specifically Palestinian identity of a territorial area and its inhabitants, and their diverse cultures and faiths. Outside official Mandate administration publications he had more freedom to articulate a national identity, but his guidebooks echo the cultural and religious diversity expressed in the Evliya translations; Stephan may in his guides choose to foreground his Christian faith, perhaps with an eye to his British readership, but this is still portrayed as irrevocably linked to the same Palestinian identity as his Muslim neighbours.

If any lesson can be drawn from Makhouly and Stephan's positions in the Department of Antiquities, it is that an overarching categorisation as Christian is of limited use in understanding their experiences. Access to missionary schooling and other forms of European soft power in the late Ottoman period may have helped both to enter civil service jobs, and may have made them more comfortable in this environment than a middle-class Muslim might have been. Being Christian may also have encouraged them to be interested in the diverse and ancient aspects of Palestinian history rather than its recent periods, more dominated by Islam. Despite the Mandate administration's orientalist enforcement of divisions between Christians and Muslims in Palestine, employees of the two faiths were united by the fact that they would never ascend beyond a certain professional status; under colonial rule, only British archaeologists would occupy the top positions in the Department. And, of course, it was as Palestinians, irrespective of denomination, that both Makhouly and Stephan became refugees in 1948. To disaggregate their influences, then, we must look perhaps to the dominance of Jerusalem in all things concerned with the Mandate administration, giving Stephan access to professional encounters, scholarly conversations and the infrastructure of publishers, radio, and printing presses; Makhouly seems distant from all of this in Akka and Nazareth, ironically more embedded in ordinary Palestinian Arab life than Stephan with his more nationalist outlook.

\section{BIBLIOGRAPHY}

Abboushi, W. F. “The Road to Rebellion: Arab Palestine in the 1930s." Journal of Palestine Studies 6, no. 3 (Spring, 1977): 23-46.

Abu El-Haj, Nadia. "Producing (Arti)Facts: Archaeology and Power During the British Mandate of Palestine." Israel Studies 7, no. 2 (2002): 33-61.

Bahrani, Zainab, Edhem Eldem and Zeynep Celik, eds. Scramble for the Past: A Story of Archaeology in the Ottoman Empire, 1753-1914. Istanbul: SALT/Garanti Kültür, 2011.

Bar-Yosef, Eitan. The Holy Land in English Culture 1799-1917: Palestine and the Question of Orientalism. Oxford: Clarendon Press, 2005. 
Bennett, Paul and Ahmed Buzaian. "Abdulhamid Abdussaid." Libyan Studies 48 (2017): 7-8.

Blackwell, Stephen. "Saving the King: Anglo-American Strategy and British CounterSubversion Operations in Libya, 1953-59." Middle Eastern Studies 39, no. 1 (2003): 1-18.

Canaan, Tawfiq. The Palestine Arab Cause. Jerusalem: The Modern Press, 1936.

- Conflict in the Land of Peace. Jerusalem: Syrian Orphanage Press, 1936.

Celik, Zeynep. About Antiquities: Politics of Archaeology in the Ottoman Empire. Austin: University of Texas Press, 2016.

Clarke, David. "Theorising the Role of Cultural Products in Cultural Diplomacy from a Cultural Studies perspective." International Journal of Cultural Policy 22, no. 2 (2016): 147-163.

Cohen, Hillel. Army of Shadows: Palestinian Collaboration with Zionism, 1917-1948. Berkeley: University of California Press, 2008.

Corbett, Elena. Competitive Archaeology in Jordan: Narrating Identity from the Ottomans to the Hashemites. Austin: University of Texas Press, 2014.

Davis, Thomas. Shifting Sands: The Rise and Fall of Biblical Archaeology. Oxford: Oxford University Press, 2004.

Davis, Miriam. Dame Kathleen Kenyon: Digging Up the Holy Land. Abingdon: Routledge, 2016.

Dever, William G. "What Remains of the House That Albright Built?" The Biblical Archaeologist 56, no. 1 (1993): 25-35.

Fanon, Frantz. The Wretched of the Earth, trans. Richard Philcox. New York: Grove Press, 2004.

Faucher, Charlotte. "Cultural Diplomacy and International Cultural Relations in Twentieth-Century Europe.” Contemporary European History 25, no. 2 (2016): 373-385.

Feldman, Ilana. Governing Gaza: Bureaucracy, Authority and the Work of Rule, 191767. Durham: Duke University Press, 2008.

Furani, Khaled and Dan Rabinowitz. "The Ethnographic Arriving of Palestine." Annual Review of Anthropology 40 (2011): 475-491.

Gibson, Shimon. "British Archaeological Institutions in Mandatory Palestine, 19171948." Palestine Exploration Quarterly 131, no. 2 (1999): 115-143.

Glock, Albert, Lois Glock, and Nancy Lapp. "Archaeology." In Encyclopedia of the Palestinians, edited by Philip Mattar, 71-80. New York: Infobase Publishing, 2005.

Glock, Albert. "Cultural Bias in the Archaeology of Palestine." Journal of Palestine Studies 24, no. 2 (Winter, 1995): 48-59.

—. "Jenin." In Anchor Bible Dictionary, 678-680. New York: Doubleday, 1992.

Green, John. "Archaeology and Politics in the Holy Land: The Life and Career of P. L. O. Guy." Palestine Exploration Quarterly 141, no. 3 (2009): 167-187.

Haiduc-Dale, Noah. Arab Christians in British Mandate Palestine: Communalism and Nationalism 1917-48. Edinburgh: Edinburgh University Press, 2013.

Hamilton, R. W. Letters from the Middle East by an Occasional Archaeologist. Durham: Pentland Press, 1992.

Irving, Sarah. "Stephan Hanna Stephan and Evliya Çelebi's Book of Travels." In Cultural Entanglement in the pre-Independence Arab World: Arts, Thought and Literature, edited by Anthony Gorman and Sarah Irving. London: I. B. Tauris, 2020, 217-237. 
- "A Young Man of Promise: Finding a Place for Stephan Hanna Stephan in the History of Mandate Palestine.” Jerusalem Quarterly 73 (2018): 42-62.

- "A Tale of Two Yusifs: Recovering Arab Agency in Palestine Exploration Fund Excavations 1890-1924." Palestine Exploration Quarterly 149 (2017): 223-236.

Kestenian, Hratch Yervant. "A Portrait of Armenian Student Life at the Syrian Protestant College, 1885-1920.” MA thesis, American University of Beirut, 2015.

Kletter, Raz, Just Past?: The Making of Israeli Archaeology. Sheffield: Equinox Publishing, 2006.

Kraeling, Carl, Ptolemais: City of the Libyan Pentapolis. Chicago: University of Chicago Press, 1962.

Lockman, Zachary. Comrades and Enemies: Arab and Jewish Workers in Palestine, 1906-48. Berkeley: University of California Press, 1996.

Long, Burke O. Planting and Reaping Albright: Politics, Ideology, and Interpreting the Bible. University Park, PA: Penn State University Press, 2010.

Maffi, Irene. "The Emergence of Cultural Heritage in Jordan: The Itinerary of a Colonial Invention." Journal of Social Archaeology 9, no. l (2009): 5-34.

Makhouly, Na'im. "El Hamme: Discovery of Stone Seats.” QDAP 6, no. 1 (1936): 59-62.

- Guide to Acre. Jerusalem: Government of Palestine Department of Antiquities/Azriel Press, 1941.

—. "Rock-Cut Tombs at El Jish." Quarterly of the Department of Antiquities of Palestine 8 (1938): 45-50.

—. "A Sixth-Century Synagogue at 'Isfiya. I Excavation Report by N. Makhouly; II The Mosaic Floor, the Inscription, Conclusion, by M. Avi-Yonah.” QDAP 3 (1934): 118-144.

Mansour, Atallah, Narrow Gate Churches: The Christian Presence in the Holy Land Under Muslim and Jewish Rule. Pasadena: Hope Publishing House, 2004.

Matthews, Weldon. Confronting an Empire, Constructing a Nation: Arab Nationalists and Popular Politics in Mandate Palestine. London: I.B. Tauris, 2006.

Megaw, A. H. S. "A Muslim Tombstone from Paphos." Journal of the Royal Asiatic Society of Great Britain and Ireland 3/4 (1950): 108-109.

Moorey, P. R. S. A Century of Biblical Archaeology. Cambridge: Lutterworth Press, 1991.

Moscrop, John James. Measuring Jerusalem: The Palestine Exploration Fund and British Interests in the Holy Land. Leicester: Leicester University Press, 2000.

Murre-van den Berg, Heleen. “A Center of Transnational Syriac Orthodoxy: St. Mark's Convent in Jerusalem." Journal of Levantine Studies 3, no. 1 (2013): 59-81.

Norris, Jacob. Land of Progress: Palestine in the Age of Colonial Development, 19051948. Oxford: Oxford University Press, 2013.

Pedley, John Griffiths. "The Archaic Favissa at Cyrene." American Journal of Archaeology 75, no. 1 (1971): 39-46.

Perrot, Jean. "La Musée archéologique de Palestine, à Jérusalem.” Syrie 25, nos. 3-4 (1946): 268-300.

Reid, Donald Malcolm. Contesting Antiquity in Egypt: Archaeologies, Museums, and the Struggle for Identities from World War I to Nasser. Cairo: American University of Cairo Press, 2015.

- Whose Pharaohs?: Archaeology, Museums, and Egyptian National Identity from Napoleon to World War I. Berkeley: University of California Press, 2003. 
Rivlin, Benjamin. "The Italian Colonies and the General Assembly." International Organization 3, no. 3 (August 1949): 459-470.

Robson, Laura. Colonialism and Christianity in Mandate Palestine. Austin: University of Texas Press, 2011.

Sanchez Summerer, K. M. J. "Preserving the Catholics of the Holy Land or Integrating Them into the Palestine Nation (1920-1950)?" In Modernity, Minority, and the Public Sphere: Jews and Christians in the Middle East, edited by S. R. Goldstein-Sabbah and H. L. Murre-van den Berg, 121-154. Leiden: Brill, 2016.

Sharvit, Jacob and Dror Planer. "'Akko, the Southern Seawall: Preliminary Report." Hadashot Arkheologiyot 126 (2014). http://www.hadashot-esi.org.il/report detail_eng.aspx?id=10574\&mag_id=121. Accessed February 2019.

Silberman, Neil Asher. Digging for God and Country: Exploration in the Holy Land, 1799-1917. New York: Anchor Books, 1982.

Stephan, Stephan Hanna. "Mawqi' al-qabr al maqdis: rad 'alaa maqal." Al-Siyasa al-Usbu'iyya, 5 November 1927.

—. "al-Mar'a.” Majallat Sarkis 11, no. 1 (January 1922): 64-65.

—. "Modern Palestinian Parallels to the Song of Songs." Journal of the Palestine Oriental Society 2 (1922): 199-278.

- A Post-War Bibliography of the Near-Eastern Mandates, 1919-1930. Beirut: American University, 1936.

Stephan, Stephan Hanna and Boulus 'Afif. This Is Palestine: A Concise Guide to the Important Sites in Palestine, Transjordan and Syria. Jerusalem: Bayt-ul-Makdes Press, 1942.

Talmon-Heller, Daniella. "Job (Ayyūb), Husayn and Saladin in Late Ottoman Palestine: Religious Life and Local History in the Memoirs of Nu mān al-Qasāṭ̂i, the Arab Scribe of the Survey of Western Palestine, and Beyond." In Exploring the Holy Land: 150 Years of the Palestine Exploration Fund, edited by David Gurevich and Anat Kidron, n.p. Sheffield: Equinox Publishing, 2019.

Tamari, Salim. Mountain Against the Sea. Berkeley: University of California Press, 2009.

Thornton, Amara "Archaeologists-in-Training: Students of the British School of Archaeology in Jerusalem, 1920-1936." Journal of Open Archaeology Data 1 (2012). http://doi.org/10.5334/4f293686e4d62.

- "Tents, Tours, and Treks: Archaeologists, Antiquities Services, and Tourism in Mandate Palestine and Transjordan.” Public Archaeology 11, no. 4 (2012): 195-216.

Whitcomb, Donald. “Dimitri Baramki: Discovering Qasr Hisham.” Jerusalem Quarterly 55 (2013): 78-82.

Worrall, Richard John. "The Strategic Limitations of a Middle East Client State by the Mid-1950s: Britain, Libya and the Suez Crisis." Journal of Strategic Studies 30, no. 2 (2007): 309-347.

Wright, G. R. H. “Obituary: C.N. Johns.” Libyan Studies 24 (1993): iv-vi.

Zgaier, Ali. "Rasa'il wa-taqrir katabha mufattish al-athar Na'im Makhouly min Kufr Yasif" (Letters and reports written by Antiquities Inspector Na'im Makhouly from Kufr Yasif), Al-Madar, 14 August 2016. http://www.almadar.co.il/news12,N-66149.html. Accessed February 2019. 
Open Access This chapter is licensed under the terms of the Creative Commons Attribution 4.0 International License (http://creativecommons.org/licenses/ by/4.0/), which permits use, sharing, adaptation, distribution and reproduction in any medium or format, as long as you give appropriate credit to the original author(s) and the source, provide a link to the Creative Commons license and indicate if changes were made.

The images or other third party material in this chapter are included in the chapter's Creative Commons license, unless indicated otherwise in a credit line to the material. If material is not included in the chapter's Creative Commons license and your intended use is not permitted by statutory regulation or exceeds the permitted use, you will need to obtain permission directly from the copyright holder. 